\title{
PENINGKATAN AKTIVITAS DAN HASIL BELAJAR DENGAN PENERAPAN MODEL PEMBELAJARAN GUIDED TEACHING PADA MATA KULIAH EVALUASI PROSES DAN HASIL BELAJAR BIOLOGI PROGRAM STUDI PENDIDIKAN BIOLOGI STKIP PGRI SUMATERA BARAT
}

\author{
Annika Maizeli*, Siska Nerita \\ Program Studi Pendidikan Biologi STKIP PGRI Sumbar
}

(Diterima Agustus 2015, disetujui Oktober 2015)

\begin{abstract}
Based on experienced of author in learning activities on students of biology STKIP West Sumatra in IV grades. In Evaluation major and result of learning showed that the result of learning was lowed. Beside that, the activitied of student not showed satisfied in learning. it showed when the lecture has explained and given the students chanced to asked about what they not understood about the learning has been studied. The students just guiet and just taken the learning from the lecture. Beside that just fiew of students asked what they not understood about the matery. When the lecture asked about the major has been studied just fiew of students answered it. The problem of this learning to improved the activitied and result of learning of students not succed, so the author have found the another alternative solution to case this problem. The purpose of this research are to improve activities and student result of the learning in evaluation and result of learning of biology STKIP West Sumatra in IV grades.This research are action research that did in two phase. The result inn learning in cognitive. The Improved of activitied and result of learning have been done with innovative learning model Guided teaching. Based on activities learning of student that get from cycluse 1 to the cycluse 2, showed that the increase in cycluse 2 . The activities was improved when they make the task and discution $10,5 \%$. Activities of presentation was improved $4,7 \%$ and activies of asking improved 9,5\%. Activities of answered improved 39,1\%. the activities of listening explanationed the lecture was improved $8,6 \%$. The improved of result learning is $42,85 \%$.
\end{abstract}

Keywords: Action research, Guided teaching, Activities, and Result of learning.

\begin{abstract}
ABSTRAK
Berdasarkan pengalaman peneliti dalam kegiatan pembelajaran mahasiswa biologi STKIP Sumatera Barat belajar di IV nilai. Evaluasi utama dan hasil belajar menunjukkan penurunan. Selain itu, aktifitas mahasiswa menunjukkan tidak puas dalam belajar. Hal ini ditunjukkan ketika dosen selesai menerangkan dan memberikan kesempatan kepada mahasiswa untuk bertanya tentang apa yang tidak mereka pahami, mahasiswa hanya diam mengambil. Selain itu hanya


beberapa mahasiwa yang bertanya apa yang tidak mereka mengerti tentang materi tersebut. Ketika dosen bertanya tentang pokok bahasan hanya sedikit mahasiwa yang menjawab. Permasalahan pada pembelajaran ini adalah peningkatan aktifitas dan hasil yang tidak sesuai, sehingga penulis telah menemukan solusi alternatif lain untuk kasus masalah ini. Tujuan dari penelitian ini adalah untuk meningkatkan kegiatan belajar mahasiswa dan hasilnya di evaluasi, dan hasil belajar biologi STKIP Sumatera Barat dalam penelitian IV grades. Ini adalah penelitian tindakan yang lakukan dalam dua tahap. Hasil pembelajaran kognitif adalah peningkatan aktifitas dan hasil belajar dengan model pembelajaran inovatif Guided teaching. Berdasarkan kegiatan belajar siswa yang didapat dari siklus 1 ke siklus 2, menunjukkan bahwa peningkatan siklus 2. Peningkatan kegiatan ketika mereka membuat tugas dan diskusi $10,5 \%$. Kegiatan presentasi meningkat $4,7 \%$ dan aktifitas bertanya meningkat 9,5\%. Kegiatan menjawab meningkat 39,1\%. kegiatan menyimak penjelasan kuliah meningkat 8,6\%. Peningkatan hasil belajar adalah $42,85 \%$.

Katakunci: Aktifitas, Guided teaching, Hasil Pembelajaran, dan Penelitian tindakan.

\section{PENDAHULUAN}

Potensi satuan pendidikan yang dapat dikembangkan adalah dosen dan mahasiswa. Dosen dan mahasiswa dalam proses pembelajaran tidak dapat dipisahkan. Dosen dengan sejumlah tugasnya seperti fasilitator, motivator dan sebagainya. Dosen diharapkan mampu membuat perencanaan pembelajaran dengan tepat dan benar. Perencanaan yang sudah dibuat dosen hendaknya dapat disajikan dengan tepat.

Dosen sebagai pengelola kegiatan pembelajaran sangat berperan dalam keberhasilan siswa. Mengajar tidak semata-mata berorientasi pada hasil, tetapi juga berorientasi pada proses dengan harapan semakin tinggi hasil yang dicapai. Jadi pemilihan model dan metode pembelajaran yang cocok juga menentukan hasil belajar karena metode dan model adalah suatu proses dalam pembelajaran.

Mata kuliah evaluasi proses dan hasil belajar biologi merupakan salah satu Mata Kuliah Keahlian Berkarya (MKK) yang ada di Prodi Pendidikan Biologi STKIP PGRI Sumatera Barat dengan bobot 3 SKS. Mata kuliah ini membahas konsep pengukuran, penilaian, evaluasi, ranah penilaian (Taksonomi Bloom), alatalat evaluasi tes dan non tes, penilaian autentik, kaidah penulisan alat evaluasi tes dan non tes yang baik dan benar, kaidah penulisan alat evaluasi tes dan non tes 
yang baik dan benar, kisi-kisi alat evaluasi (Tes dan Non Tes), penskoran dan penilaian, analisis alat evaluasi, penetapan Kriteria Ketuntasan Minimal (KKM), dan langkah-langkah pengisian laporan hasil belajar.

Berdasarkan pengalaman penulis dalam proses pembelajaran pada mahasiswa semester IV Program Studi Pendidikan Biologi STKIP PGRI Sumatera Barat, pada matakuliah evaluasi proses dan hasil belajar biologi menunjukkan hasil yang belum memuaskan. Selain itu, aktivitas mahasiswa masih belum menunjukkan antusiasme yang baik dalam pembelajaran. Hal ini terlihat saat dosen menjelaskan materi dan memberi kesempatan kepada siswa untuk bertanya tentang materi yang telah dipelajari, terlihat bahwa mahasiswa cenderung pasif dan menerima penjelasan dari dosen saja. Selain itu, hanya beberapa mahasiswa yang bertanya terhadap materi yang masih kurang dipahami. Sewaktu dosen bertanya tentang materi yang dipelajari, beberapa orang saja yang menjawab pertanyaan tersebut.

Beberapa faktor yang penulis perkirakan sebagai penyebab terjadinya kesenjangan ini adalah: 1) belum optimalnya usaha yang penulis lakukan untuk memilih model pembelajaran yang efektif, 2) kebiasaan siswa belajar yang muncul sudah terbentuk semenjak dini, bahwa kegiatan pembelajaran terpusat pada dosen sehingga tidak adanya interaksi dosen dengan mahasiswa, mahasiswa dengan mahasiswa yang lainnya.

Melihat kondisi tersebut, penulis terdorong mengkaji berbagai aspek yang berkaitan dengan pembelajaran. Aspek-aspek yang berkaitan dengan pembelajaran menunjukkan perlu adanya perbaikan pada teknik pembelajaran yang selama ini dilakukan. Oleh karena itu, diperlukan adanya solusi yang tepat untuk perbaikan pembelajaran pada mata kuliah evaluasi proses dan hasil belajar biologi. Berdasarkan alasan tersebut, maka dilakukan penelitian tindakan kelas guna memperbaiki proses pembelajaran.

Penelitian Tindakan Kelas (PTK) merupakan suatu penelitian yang dilakukan secara sistematis reflektif terhadap berbagai "aksi" atau tindakan yang dilakukan oleh Dosen/pelaku, mulai dari perencanaan sampai dengan penilaian terhadap tindakan nyata di dalam kelas yang berupa kegiatan belajar-mengajar untuk memperbaiki kondisi pembelajaran (Arikunto, 2006). Penelitian tindakan kelas dapat dilakukan dengan mengaplikasikan suatu model pembelajaran inovatif yang 
dapat membuat siswa menjadi aktif dan kreatif dalam hal menemukan ide pokok, memecahkan persoalan, atau mengaplikasikan apa yang baru dipelajari. Selain itu, mahasiswa akan turut serta dalam proses pembelajaran sehingga dapat menikmati suasana yang lebih menyenangkan, sehingga dapat meningkatkan aktifitas dan hasil belajar. Aktivitas merupakan suatu kegiatan yang dilakukan untuk menghasilkan perubahan pengetahuan-pengetahuan, nilai-nilai, sikap dan keterampilan pada siswa sebagai latihan yang dilaksanakan secara sengaja. Menurut Slameto (2010:36) mengemukakan bahwa "penerimaan pembelajaran jika dengan aktivitas siswa sendiri, kesan itu tidak akan berlalu begitu saja, tetapi dipikirkan, diolah kemudian dikeluarkan lagi dalam bentuk yang berbeda, atau siswa akan bertanya, mengajukan pendapat, menimbulkan diskusi dengan guru".

Salah satu model pembelajaran yang dapat meningkatkan aktivitas belajar adalah model pembelajaran guided teaching. Model Pembelajaran guided teaching merupakan rangkaian penyampaian meteri ajar yang diawali dari suatu pertanyaan yang dijadikan dasar untuk menyampaikan materi berikutnya. Dalam model ini, pengajar bertanya kepada peserta didik satu atau dua pertanyaan untuk mengetahui tingkat pemahaman peserta didik atau untuk memperoleh hipotesa atau kesimpulan kemudian membaginya kepada kategori. Dengan demikian, model pembelajaran guided teaching merupakan rangkaian penyampaian meteri ajar yang diawali dari suatu pertanyaan yang dijadikan dasar untuk menyampaikan materi berikutnya ( Istarani, 2012: 226).

Menurut Istarani (2012: 227) kelebihan dari guided teaching adalah sebagai berikut ini.

1. Dapat meningkatkan motivasi belajar siswa sebab pembelajaran diawali dengan pertanyaan.

2. Melatih siswa berfikir untuk menjawab pertanyaan secara benar.

3. Dapat meningkatkan kerjasama siswa karena dalam belajar dibentuk kelompok-kelompok kecil.

Adapun kekurangan guided teaching adalah sebagai berikut ini.

1. Kadang akan terjadi kelarutan dalam pertanyaan sehingga materi yang akan diajarkan kurang tersampaikan secara baik. 
2. Lebih mengutamakan pembandingan dari materi dari pada penyampaian pesan materi yang akan disampaikan.

Menurut Istarani (2012: 226) langkah-langkah pembelajaran guided teaching adalah berikut ini.

1. Sampaikan beberapa pertanyaan kepada siswa untuk mengetahui pikiran dan kemampuan yang mereka miliki. Gunakan pertanyaan-pertanyaan yang mempunyai beberapa kemungkinan jawaban.

2. Berikan waktu beberapa menit untuk memberi kesempatan kepada siswa untuk menjawab pertanyaan. Anjurkan kepada mereka untuk bekerja berdua atau dalam kelompok kecil.

3. Mintalah kepada siswa untuk menyampaikan hasil jawaban mereka dan catat jawaban-jawaban yang mereka sampaikan. Jika memungkinkan tulis di papan tulis dengan mengelompokkan jawaban mereka dalam kategori-kategori yang nantinya akan anda sampaikan dalam pembelajaran.

4. Sampaikan poin-poin utama dari materi anda dengan ceramah yang interaktif.

5. Mintalah kepada siswa untuk membenadingkan jawaban mereka dengan poin-poin yang telah anda sampaikan. Catat poin-poin yang dapat memperluas bahasan materi anda.

Penelitian ini bertujuan untuk meningkatkan aktivitas dan hasil belajar pada mata kuliah evaluasi proses dan hasil belajar biologi mahasiswa semester IV Program Studi Pendidikan Biologi STKIP PGRI Sumatra Barat.

\section{METODE PENELITIAN}

Jenis Penelitian yang dilaksanakan adalah Penelitian Tindakan Kelas (PTK) atau Classroom Action Research (CAR). Penelitian dilakukan di STKIP PGRI Sumatera Barat semester empat pada matakuliah evaluasi proses dan hasil belajar biologi. Subjek penelitian ini adalah mahasiswa semester empat Sesi F 2012 yang mengikuti perkuliahan Evaluasi Proses dan Hasil Belajar Biologi yang berjumlah 35 orang. Penelitian dilaksanakan dengan 2 siklus, setiap siklus mencakup 3 pertemuan dengan tahapan: 1. Perencanaan. 2. Implementasi/ pelaksanaan tindakan 3. Observasi dan interpretasi. 4. Analisis dan refleksi. 
Instrument yang digunakan untuk mengumpulkan data pada penelitian adalah sebagai berikut ini.

1. Lembar observasi aktivitas mahasiswa, digunakan untuk mengetahui aktivitas mahasiswa selama proses pembelajaran berlangsung.

2. Soal yang diberikan melalui kuis pada setiap akhir siklus, digunakan untuk mendapatkan data yang diperlukan untuk melihat pemahaman mahasiswa terhadap materi yang telah dipelajari.

Data dianalisis secara deskriptif yaitu mengemukakan fakta-fakta dan temuan-temuan yang terjadi selama penelitian berlangsung. Analisis data bertujuan untuk melihat peningkatan aktivitas dan hasil belajar.

1. Analisis aktivitas belajar mahasiswa

Analisis aktivitas belajar mahasiswa digunakan rumus persentase (\%) yang dikemukakan Sudijono (2004: 43), seperti Tabel 1.

$$
P=\frac{\mathrm{f}}{N} \times 100
$$

Keterangan:

P : persentase aktivitas

F : jumlah mahasiswa yang terlibat disetiap aktivitas

$\mathrm{N} \quad$ : jumlah mahasiswa yang hadir

Indikator keberhasilan untuk aktivitas belajar siswa secara klasikal adalah $75 \%$. Jika rata-rata aktivitas mahasiswa telah mencapai $\geq 75 \%$ berarti aktivitas mahasiswa sudah berhasil.

\begin{tabular}{cc}
\multicolumn{2}{c}{ Tabel 1. Interval Aktivitas Siswa } \\
\hline Interval Skor & Kategori \\
\hline $81-100$ & Sangat Baik \\
$61-80$ & Baik \\
$41-60$ & Cukup \\
$1-40$ & Kurang \\
\hline
\end{tabular}

\section{Analisis Hasil Belajar}

Hasil belajar mahasiswa dihitung berdasarkan ketuntasan individual. Penilaian hasil belajar mengungkapkan bahwa seorang mahasiswa dikatakan tuntas belajar apabila mendapat nilai $\geq 70$. Persentase ketuntasan individual dapat dihitung dengan rumus : 
Keterangan :

$$
N I=\frac{\mathrm{T}}{\mathrm{SM}} \mathrm{X} 100 \%
$$

$\mathrm{NI}=$ Ketuntasan belajar secara individual

$\mathrm{T}=$ Skor yang diperoleh mahasiswa

$\mathrm{SM}=$ Skor Maksimum dari tes

\section{HASIL DAN PEMBAHASAN}

\section{Aktifitas}

Selama proses perkuliahan berlangsung, diadakan observasi tentang aktivitas mahasiswa dalam mengikuti kegiatan perkuliahan. Untuk mengetahui hasil observasi terhadap aktifitas mahasiswa selama penelitian, maka lembar observasi dianalisis dengan menentukan persentase setiap aktifitas yang diamati pada siklus I dan siklus II. Rata-rata persentase aktifitas mahasiswa pada siklus I dan siklus II dapat dilihat seperti pada Gambar 1 dan 2.

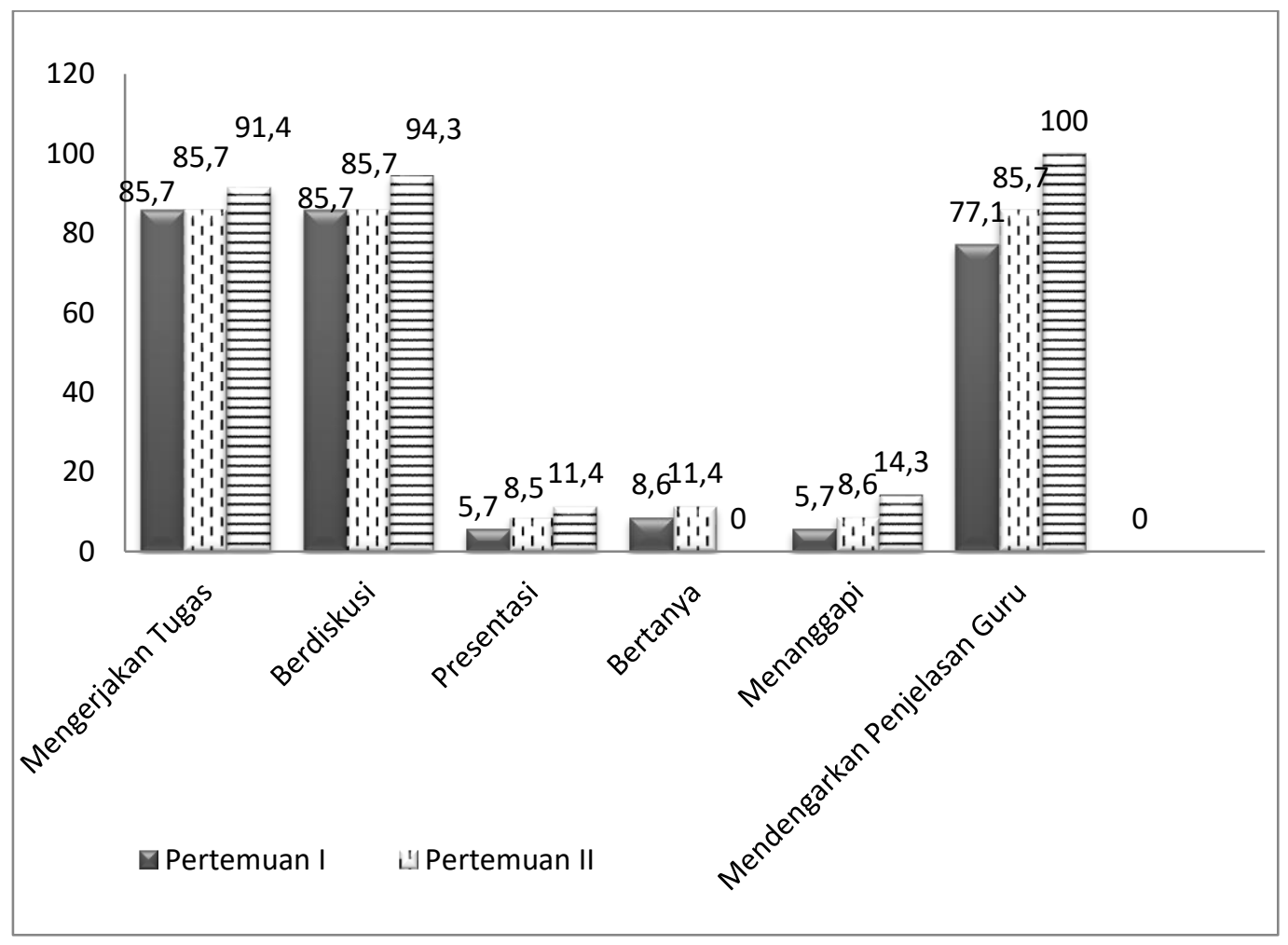

Gambar 1. Rata-rata Persentase Perkembangan Aktifitas Belajar Siklus I

Berdasarkan Gambar 1 terlihat bahwa aktifitas mahasiswa pada siklus I mengalami peningkatan pada setiap pertemuan. Aktifitas mengerjakan tugas pada pertemuan satu, rata-rata persentase $85,7 \%$, pertemuan dua $85,7 \%$ dan pertemuan tiga $91,4 \%$. Aktifitas berdiskusi pada pertemuan satu $85,7 \%$, pertemuan dua $85,7 \%$, dan pertemuan tiga $94,3 \%$. Aktifitas presentasi pada pertemuan satu $5,7 \%$, 
pertemuan dua $8,5 \%$ dan pertemuan tiga 11,4 . Aktifitas bertanya pada pertemuan satu $8,6 \%$, pertemuan dua $11,4 \%$ dan pertemuan tiga $0 \%$. Aktifitas menanggapi pada pertemuan satu $5,7 \%$, pertemuan dua $8,6 \%$ dan pertemuan tiga $14,3 \%$. Aktifitas mendengarkan penjelasan guru pada pertemuan satu $77,1 \%$, pertemuan dua $85,7 \%$ dan pertemuan tiga $100 \%$.

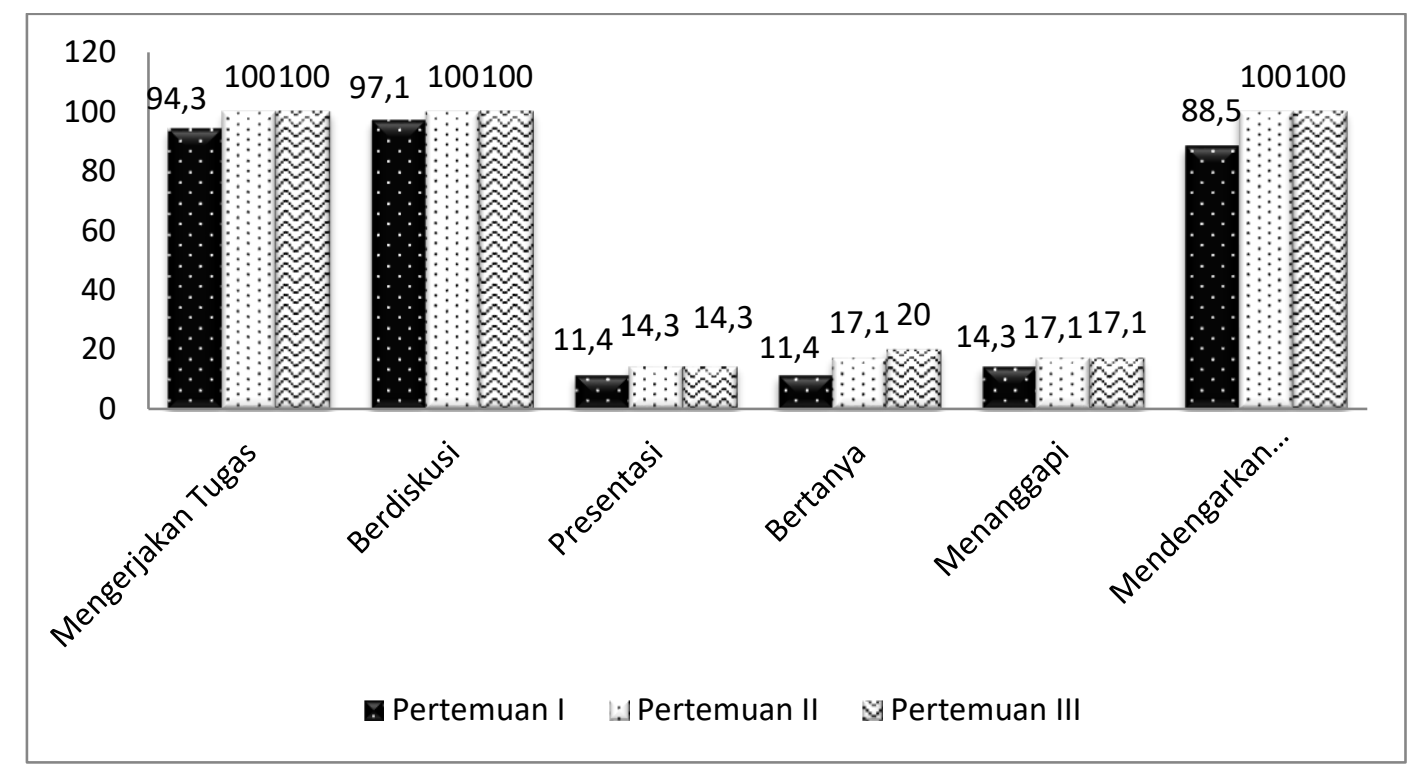

Gambar 2: Rata-rata Persentase Perkembangan Aktifitas Belajar Siklus II

Berdasarkan Gambar 2 terlihat bahwa aktifitas mahasiswa siklus II mengalami peningkatan pada setiap pertemuan. Aktifitas mengerjakan tugas pada pertemuan satu rata-rata persentase $94,3 \%$, pertemuan dua $100 \%$ dan pertemuan tiga $100 \%$. Aktifitas berdiskusi pada pertemuan satu 97,1\%, pertemuan dua $100 \%$, dan pertemuan tiga $100 \%$. Aktifitas presentasi pada pertemuan satu 11,4\%, pertemuan dua $14,3 \%$ dan pertemuan tiga 14,3 . Aktifitas bertanya pada pertemuan satu $11,4 \%$, pertemuan dua $17,1 \%$ dan pertemuan tiga $20 \%$. Aktifitas menanggapi pada pertemuan satu $14,3 \%$, pertemuan dua $17,1 \%$ dan pertemuan tiga $17,1 \%$. Aktifitas mendengarkan penjelasan guru pada pertemuan satu 88,5\%, pertemuan dua $100 \%$ dan pertemuan tiga $100 \%$ 


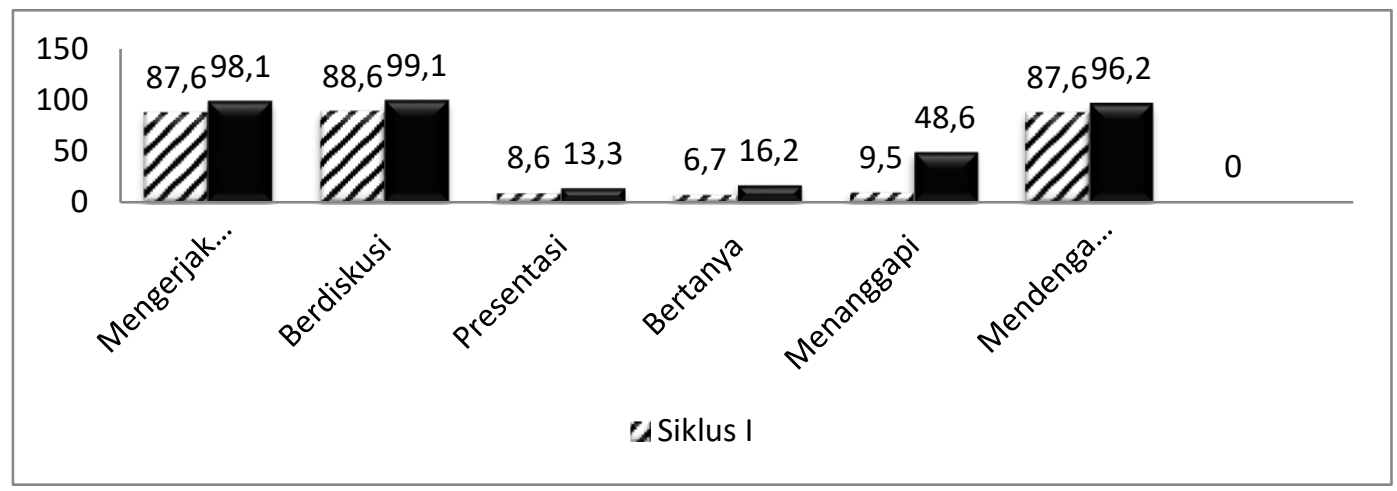

Gambar 3:Rata-rata Persentase Perkembangan Aktifitas Mahasiswa Siklus I dan II

Berdasarkan Gambar 3 terlihat adanya peningkatan rata-rata persentase aktifitas belajar mahasiswa dari siklus I ke siklus II. Rata -rata persentase aktifitas mengerjakan tugas pada siklus I 87,6 \% (sangat baik) meningkat menjadi 98,1\% (sangat baik). Aktifitas berdiskusi pada siklus I 88,6 \% (sangat baik) meningkat menjadi 99,1 \% (sangat baik). Aktifitas presentasi pada siklus I 8,6 \% C meningkat menjadi 13,3 \% (kurang). Aktifitas bertanya pada siklus I 6,7 \% (kurang) meningkat menjadi 16,2 \% (kurang). Aktifitas menanggapi pada siklus I 9,5\% (kurang). meningkat menjadi 48,6 \% (cukup) pada siklus II. Aktifitas mendengarkan penjelasan dosen pada siklus I 87,6 \% (sangat baik) meningkat menjadi 96,2\% (sangat baik).

\section{Hasil Belajar}

Hasil belajar mahasiswa diperoleh melalui tes yang diberikan diakhir siklus. Tes diberikan berupa soal uraian. Pada siklus I soal yang diberikan berjumlah 3 buah soal dan siklus II empat buah soal. Nilai rata-rata mahasiswa yang diperoleh dapat terlihat seperti Gambar 4. 


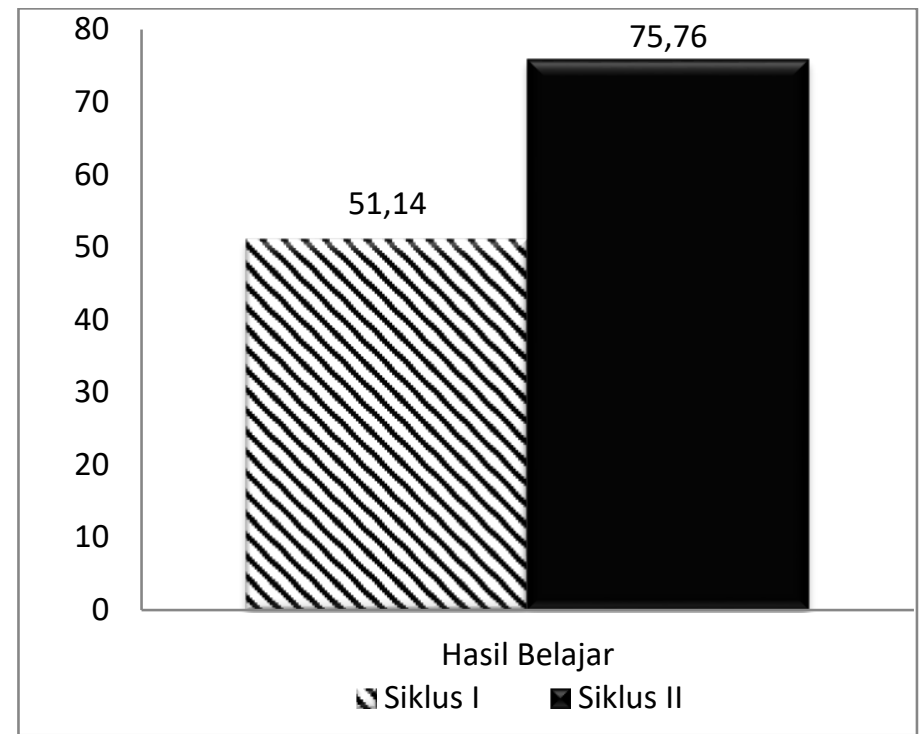

Gambar 4. Rata- rata Persentase Hasil Belajar Mahasiswa

Berdasarakan gambar 4 terlihat bahwa adanya peningkatan hasil belajar mahasiswa dari siklus I ke seiklus II. Rata-rata hasil belajar mahasiswa pada siklus I 51,14 sedangkan pada siklus II 75,76.

\section{B. Pembahasan}

\section{Aktifitas mahasiswa}

Tahap pengamatan (observasi) dilaksanakan bersamaan saat tindakan dilaksanakan. Pengamatan dilakukan oleh observer dengan panduan lembaran observasi. Adapun pengamatan yang dilakukan diantaranya:

a. Mengerjakan tugas dan berdiskusi

Aktifitas mengerjakan tugas dan berdiskusi yang terlihat pada gambar 5 terjadinya peningkatan $10,5 \%$ dari siklus I ke siklus II. Hal ini disebabkan karena mahasiswa termotivasi untuk mengerjakan tugas, dimana dalam penerapan model pembelajaran yang digunakan menuntut adanya tanggung jawab individu dan kerjasama dalam berdiskusi. Oleh karena itu, masing-masing kelompok berusaha mengerjakan tugas dengan maksimal. Hal ini sesuai menurut Hamdani (2011:51) bahwa belajar akan berlangsung dengan baik dan meningkat 
kualitasnya apabila berdiskusi, saling bertanya dan mempertanyakan atau saling menjelaskan.

b. Presentasi dan bertanya

Aktifitas presentasi dan bertanya yang terlihat pada gambar 3 terjadinya peningkatan $4,7 \%$. Aktifitas bertanya terjadinya peningkatan 9,5\%. Hal ini disebabkan karena berdasarkan pengamatan yang dilakukan terlihat kurangnya mahasiswa dalam berkomunikasi selama diskusi kelompok besar dilaksanakan. Hal ini dapat terlihat pada saat mereka mengajukan pertanyaan dan mengemukakan pendapat.

c. Menanggapi

Aktifitas menanggapi yang terlihat pada gambar 3 terjadinya peningkatan 39,1\%. Hal ini disebabkan karena mahasiswa telah memahami konsep yang diberikan melalui pertanyaan yang ada pada tugas yang dikerjakannya. Selain itu, selama berdiskusi mereka saling bertukar fikiran dan mengeluarkan ide-ide mereka sehingga lebih memahami materi yang dipelajari.

d. Mendengarkan penjelasan dosen

Aktifitas mendengarkan penjelasan dosen yang terlihat pada gambar 3 terjadinya peningkatan $8,6 \%$. Hal ini disebabkan karena mahasiswa sudah termotivasi dalam belajar. Selain itu, mereka ingin mengetahui apakah pertanyaan yang dikerjakan dengan anggota kelompok sudah memiliki konsep yang benar sesuai dengan penjelasan yang disampaikan dosen.

Mahasiswa sudah memahami bahwa memperhatikan penjelasan yang disampaikan dosen sangat bermanfaat dan berpengaruh terhadap proses pembelajaran yang berlangsung hingga selesai. Menurut teori belajar Ausubel bahan pelajaran yang dipelajari haruslah "bermakna" (meaning full). Pembelajaran bermakna merupakan suatu proses mengaitkan informasi baru pada konsep-konsep relevan yang terdapat dalam struktur kognitif seseorang. Struktur kognitif ialah fakta-fakta, konsep-konsep, dan generalisasi-generalisasi yang telah dipelajari dan di ingat siswa. 


\section{Hasil belajar}

Peningkatan aktivitas siswa dengan menggunakan model pembelajaran inovatif guided teaching ini memberi pengaruh terhadap peningkatan hasil belajar siswa. Dari hasil penelitian yang diperoleh terlihat terjadinya peningkatan hasil belajar siswa. Rata-rata hasil belajar mahasiswa meningkat dari siklus I ke siklus II. Pada siklus I rata-rata hasil belajar mahasiswa 51,14 sedangkan siklus II 75,76. Pada siklus I mahasiswa yang tuntas $40 \%$ sedangkan yang tidak tuntas $60 \%$. Pada siklus II mahasiswa yang tuntas $82,85 \%$ dan yang tidak tuntas $17,15 \%$. Disini terlihat bahwa terjadi peningkatan persentase hasil belajar mahasiswa dari siklus I ke siklus II.

Peningkatan ini terjadi karena mahasiswa lebih termotivasi untuk belajar dimana sebelum pembelajaran dimulai diawali dengan pemberian pertanyaan yang dapat memancing daya fikir mahasiswa. Selain itu, dalam menjawab pertanyaan, mahasiswa berdiskusi dan saling bekerjasama sesama anggota kelompok. Hal ini sesuai menurut Istarani (2012: 227) bahwa model pembelajaran inivatif guided teaching dapat meningkatkan motivasi siswa dalam belajar, melatih siswa untuk berfikir secara individu dan mampu bekerjasama dengan anggota kelompoknya.

Saat berdiskusi mereka saling berbagi dan mengeluarkan ide-ide dalam menyelesaikan tugas yang diberikan, sehingga mahasiswa lebih memahami konsep-konsep dari materi yang dipelajari dengan baik. Hal ini menyebabkan mahasiswa dapat menyelesaikan soal yang diberikan pada tes akhir, sehingga hasil belajar meningkat. Menurut Purwanto (2010:112) menyatakan bahwa hasil belajar yang dicapai oleh siswa dalam tes adalah $75 \%$ atau lebih, siswa tersebut dipandang telah menguasai bahan pelajaran yang bersangkutan.

Peningkatan yang terjadi pada hasil belajar dipengaruhi oleh adanya aktifitas dari mahasiswa dan faktor pendekatan belajar yang meliputi strategi dan metode yang digunakan untuk melakukan kegiatan pembelajaran. Menurut Nana (2004:9) semakin tinggi aktivitas mental semakin berbobot aktivitas belajar siswa, dan semakin kompleks usaha guru dalam melaksanakan proses pembelajaran. Ini berarti perlu ada keseimbangan antara aktivitas belajar siswa dengan aktivitas guru mengajar, dengan demikian dapat pula dikatakan bahwa belajar yang optimal 
adalah belajar yang melibatkan aktivitas mental dan fisik siswa secara maksimal dalam kegiatan belajar.

\section{KESIMPULAN DAN SARAN}

\section{A. Kesimpulan}

Setelah dilakukan penelitian tindakan kelas pada siklus I dan siklus II, hasil dari observasi dan hasil refleksi dapat disimpulkan sebagai berikut ini.

1. Telah terdapat peningkatan aktivitas belajar mahasiswa sesi F 2012 pada mata kuliah evaluasi proses dan hasil belajar biologi dengan penerapan model pembelajaran inovatif guided teaching. Aktifitas pada siklus I dengan kritera cukup sedangkan aktifitas pada siklus II dengan kriteria baik.

2. Telah terjadi peningkatan hasil belajar mahasiswa sesi F 2012 pada mata kuliah evaluasi proses dan hasil belajar biologi dengan penerapan model pembelajaran inovatif guided teaching. Perbandingan hasil belajar pada siklus I persentase siswa yang mencapai ketuntasan sebesar 40\%, sedangkan pada siklus II persentase siswa yang mencapai ketuntasan sebesar $82,85 \%$ dengan selisih perbandingan $42,85 \%$. Jika dilihat secara keseluruhan telah terjadi peningkatan hasil belajar pada siklus II, hal ini sudah mencapai target yang telah ditetapkan

\section{B. Saran}

1. Peneliti menyarankan agar tetap melakukan inovasi, variasi dalam pembelajaran sebagai upaya dalam meningkatkan aktivitas dan hasil belajar mahasiswa.

2. Kepada dosen hendaknya membiasakan diri dengan menggunakan pembelajaran model pembelajaran inovaif guided teaching yang dapat menjadikan siswa ikut berperan aktif dalam menunjang proses pembelajaran. 


\section{DAFTAR PUSTAKA}

Arikunto, Suharsimi. 2006. Dasar-dasar Evaluasi Pendidikan. Jakarta: Bumi Aksara

Istarani. 2012. 58 Model Pemebelajaran Inovatif. Medan: Media Persada

Nana Syaodih, Sukmadinata. 2004. Landasan Psikologi Proses Pendidikan. Bandung : Remaja Rasda Karya

Purwanto, Ngalim. 2010. Prinsip-prinsip dan Teknik Evaluasi Pengajaran. Bandung Remaja Rosdakarya

Slameto. 2003. Belajar dan Faktor-faktor yang Mempengaruhinya. Jakarta: Rineka Cipta

Sudijono, Anas. 2004. Pengantar Statistik Pendidikan. Jakarta: Raja Grafindo Persada

Slameto. 2010. Belajar dan Faktor-faktor Yang Mempengaruhinya. Jakarta : Rineka Cipta. 